\title{
Maturity size and fecundity of hybrid tilapia Oreochromis aureus X Oreochromis niloticus (Perciformes: Cichlidae) from the reservoir Fernando Hiriart Balderrama "Zimapan", Hidalgo, Mexico
}

\author{
Mario Alejandro Gómez-Ponce ${ }^{1 *}$, Claudio Manuel Padilla -González², Martín López-Hernández³, Gabriel Núñez- \\ Nogueira ${ }^{1} \&$ Laura Fernández-Bringas ${ }^{1}$ \\ 1. Estación el Carmen, Instituto de Ciencias del Mar y Limnología, UNAM. Kilómetro 9.5, carretera Carmen-Puerto Real. C.P. 24157. Ciudad del \\ Carmen, Campeche, México, Telephone/fax +52 9383831846; mgomez@cmarl.unam.mx; gnunez@cmarl.unam.mx; If_bringas@yahoo.com \\ 2. Laboratorio de Tratamiento de Aguas, Facultad de Ingeniería, Universidad Autónoma de San Luis Potosí, Av. Dr. Manuel Nava 6, San Luis \\ Potosí, SLP C.P. 78210, México; padillacm@yahoo.com \\ 3. Unidad Académica de Procesos Oceanícos y Biodiversidad Acuática, Instituto de Ciencias del Mar y Limnología, UNAM. Circuito Exterior S/N \\ Ciudad Universitaria. Delegación Coyoacán C.P. 04510, México, D F; martinl@cmarl.unam.mx
}

Received 2-XI-2013 • Corrected 28-II-2014 • Accepted 27-III-2014

\begin{abstract}
Maturity size and fecundity of hybrid tilapia Oreochromis aureus $X$ Oreochromis niloticus. (Pisces: Cichlidae) from the reservoir Fernando Hiriart Balderrama "Zimapan", Hidalgo, Mexico were determined in organisms caught between 2007 and 2008. A total of 506 hybrid fishes were captured and showed a range of sizes from 20 to $28,9 \mathrm{~cm}$ standard length $\left(S_{L}\right)$, and total weight of 200 to $750 \mathrm{~g}\left(T_{\mathrm{w}}\right)$. The estimated maturation size for females was $20,8 \mathrm{~cm}$ and $22 \mathrm{~cm}$ for males, respectively. Fecundity was estimated on 50 gonads and a mean of 3 $113 \pm 1826$ eggs was recorded per gravid female. Based on these results, these fishes are suitable for commercial exploitation and imply good conservation in correlation to the regulatory strategies for fisheries established in the area, at least from a reproductive point of view.
\end{abstract}

Key words: sexual ratio, hybrid, fecundity, gonadic maturity, condition factor.
RESUMEN: La biología reproductiva de la tilapia hibrida Oreochromis aureus $X$ Oreochromis niloticus en la presa Zimapán fue analizada en organismos colectados entre 2007 y 2008. Un total de 502 peces fueron capturados y mostraron un intervalo de tallas que varió de 20 a 28,9 $\mathrm{cm}$ de longitud standard $\left(\mathrm{S}_{\mathrm{L}}\right)$ y un peso total de 200 a $750 \mathrm{~g}\left(T_{w}\right)$. Los especímenes mostraron una tasa de crecimiento isométrico. La talla estimada de madurez en hembras fue de $20,8 \mathrm{~cm}$ y $22 \mathrm{~cm}$ para machos, respectivamente. La fecundidad se estimó en una muestra de 50 gónadas y se obtuvo un promedio de $3113 \pm 1826$ huevos por hembra grávida. Basados en estos resultados, estos peces son susceptibles de explotación comercial y muestran cierto estado de conservación como recurso pesquero, probablemente como resultado de las estrategias regulatorias de pesquerías existentes en el área, al menos desde la perspectiva reproductiva.

Palabras claves: proporción sexual, híbrido, fecundidad, madurez gonadal, factor de condición.
Cichlids are distributed worldwide, their origin is in Africa and Madagascar but they have been introduced in to many tropical and subtropical countries, including those of Central and South America (Fryer \& lles, 1972; Morales, 1991). In 1976, Oreochromis niloticus (Lineaus, 1758), Nile Tilapia, was introduced in to Mexico after a previous introduction in Panama (Arredondo-Figueroa \& Tejeda-Salinas, 1989). Tilapia is one of the three most important freshwater fisheries in Mexico; the annual production of Tilapia in 2008 was 71312 tonnes representing about $48,31 \%$ of the country's total inland fishery production (SAGARPA, 2008). Scientific investigation of the natural resources present in Mexican reservoirs have mainly focused on the capacity for their commercial exploitation as a fishery resource, due to their social and economic importance, however, some biological aspects such as reproductive condition or conservation status are poorly understood and studied (López-Hernández, Ramos, Gómez-Ponce, Figueroa-Torres \& Carranza-Fraser, 2007). The Zimapan reservoir has an area of $22,9 \mathrm{~km}^{2}$ and is located on the boundary of the states of Queretaro and Hidalgo, between the watersheds of the Tula and 
San Juan rivers. Commercial exploitation of the fishery began in 1998. Due to social and economic pressure present in this region, fishing has become a key source of income for local communities (Hernández-Montaño \& Orbe-Mendoza, 2002). Currently, residents of coastal communities on both shores of the reservoir (Queretaro and Hidalgo States) have a strong interest in fishing, with captures mainly represented by Tilapia (Oreochromis spp. Günther, 1889), while Common carp (Cyprinus carpio speculari, Linnaeus 1758) and Largemouth bass (Micropterus salmoides salmoides (Lacepède, 1802)) are caught incidentally.

Some more recent studies have been focused on fishery aspects of tilapia in Zimapan (Arellano-Torres, Hernández \& Melendez, 2013; Gómez-Ponce, GranadosFlores, Padilla, López-Hernández \& Núñez-Nogueira, 2011; Hernández-Montaño \& Meléndez-Galicia, 2010; Hernández-Montaño \& Orbe-Mendoza, 2002; LópezHernández et al., 2007; Hernández-Montaño \& OrbeMendoza, 1999) and other fishes (Bermúdez, 2007; Hernández-Montaño \& Orbe-Mendoza, 1999), but very few on its reproduction (Hernández-Montaño \& Meléndez-Galicia, 2010; Hernández-Montaño \& OrbeMendoza, 2002). These studies have been important for sustainable management strategies established of this resource in the reservoir. Fish closed season has been establishes from April 25 to June 20 as a regulatory strategy for conservation of local Tilapia fisheries (SAGARPA, 2013), considering minimum catch size for commercial porpoises of $23,0 \mathrm{~cm}$ standard length (DOF, 2007; Hernández-Montaño \& Meléndez-Galicia, 2010). This study analyzed the reproductive biology of hybrid tilapia (Oreochromis aureus $x$ Oreochromis niloticus.) specifically the reproductive length at first maturity, sex ratio and fecundity, providing a baseline for future studies, and its implication on local fishery conservation respect of regulatory strategies established for the Zimapan reservoir.

\section{MATERIALS AND METHODS}

This study was carried out in the Zimapan reservoir which is located on the boundary between the states of Queretaro and Hidalgo $\left(20^{\circ} 38^{\prime} 50.90^{\prime \prime} \mathrm{N}\right.$ and $99^{\circ} 29^{\prime} 19.90^{\prime \prime}$ ). Samples from the commercial catch were taken in several localities (El Rito, Manguani, Tzibanza, La Cortina, El Epazote, Noxthey y La Florida) at approximately monthly intervals from May 2007 to April 2008. Fish were caught by static commercial gill nets of 4,5 inches, with a maximum length of $60 \mathrm{~m}$, height of $5 \mathrm{~m}$ and an aperture of $11,43 \mathrm{~cm}$, as a part of an age-growth study (Gómez-Ponce et al., 2011).

The nets were placed in the late afternoon and collected the next morning. The organisms were identified using dichotomous keys (Trewavas, 1983; ArredondoFigueroa \& Guzmán-Arroyo, 1986). All the specimens caught and analyzed showed features of hybridization as was established previously (Gómez-Ponce et al., 2011). For each fish, the standard length $\left(S_{L}\right)$ was obtained by measuring from the tip of the snout to the base of the caudal peduncle. Total length is not reported as several fishes had damaged or bitten caudal fins. For the registration of the standard length we used a graded ruler of $50 \mathrm{~cm}$ with $1 \mathrm{~mm}$ accuracy. Total weight $\left(T_{w}\right)$ was expressed in grams and weighed with a scale $\left(\mathrm{OHAUS}^{\mathrm{TM}}\right.$ $10 \mathrm{~kg}$ ) with an interval of 0.1 grams of precision. Fishes were separated by sex and the sex ratio was recorded by date of collection.

The size at first maturity was determined when height at which $50 \%$ of the cumulative relative frequency of specimens were in ripe stage (phase IV) of the maturity scale of Nikolsky (1963). To calculate the size at first maturity the data were fitted to logistic models (Sparre \& Venema, 1997) as follows:

$$
P i=\frac{1}{1+e^{a-b S L}}
$$

Where $P i$ is the proportion of mature fish defined by length interval and $a$ and $b$ are model parameters. Once fitted, the size at first maturity (the length at which $50 \%$ of the fish are reproducing, $L \mathrm{~m} 50 \%$ ) was calculated as $\mathrm{Lm}$ $50 \%=a / b$.

For fecundity determination, 50 gonads were randomly selected and a subsample of $1 \mathrm{~g}$ dissected for egg counting, assisted by a stereoscopic microscope $\left(\right.$ Leica $\left.{ }^{\mathrm{TM}}\right)$. The fecundity was estimated using the total number of eggs (Total Fecundity) contained in the ovary of the fish. The gonadosomatic index (GSI) for each fish was calculated based on the weight, expressed as percentage (de Vlaming, Grossman \& Chapman, 1982). The monthly frequency of the various maturity stages determinate using the table proposed by Nikolski (1963) was plotted, and mean females fish (248) were used for fecundity estimations.

A correlation analysis was performed between the number of eggs and standard length $\left(S_{L}\right)$, and between number of eggs and total weight $\left(T_{w}\right)$. 


\section{RESULTS}

Based on the main anatomical features considered for taxonomical identification (Trewavas, 1983, ArredondoFigueroa \& Guzmán-Arroyo, 1986) the Tilapias from Zimapan reservoir share features from two of the originally introduced species (Oreochromis niloticus (Linnaeus, 1758) and Oreochromis aureus (Steindachner, 1864)) (Table 1). In this study all organisms were considered as hybrids (Oreochromis niloticus $x$ Oreochromis aureus; Gómez-Ponce et al., 2011).
A total of 506 fishes ranging from 20 to $28,9 \mathrm{~cm}$ in standard length $\left(S_{L}\right)$, and 200 to $750 \mathrm{~g}$ in body weight, with a sex ratio of 1,06 comprised of 262 females $(51,8 \%)$ and 243 males $(48,2 \%)$ were captured. The most common size range was 21 to $25 \mathrm{~cm}$ of $S_{L}$ and a total weight of 350 to $500 \mathrm{~g}$ (Figs. 1-2). Females were more numerous from April to September and the males from January to March (Table 2). The sex ratio was 1:1.06 (females:males) and did not differ significantly of the expected ratio 1:1 $\left(x^{2}=0,02\right.$; $P=0,05)$.

TABLE 1

Summary of diagnostic morphological features considered in identifying specimens of Tilapia from Zimapan Dam.

\begin{tabular}{|c|c|c|c|}
\hline \multirow{2}{*}{ Features } & \multicolumn{3}{|c|}{ Species } \\
\hline & Oreochromis niloticus & Oreochromis aureus & Fishes from Zimapan dam \\
\hline Gill rakers number ${ }^{1}$ & $18-28$ & $18-26$ & $23-29$ \\
\hline Scales number on lateral line ${ }^{1}$ & $30-34$ & $30-33$ & $33-36$ \\
\hline Dorsal fin (modal formula) ${ }^{1}$ & XV - XVIII (13) & XIV - XVII (12-15) & XVI - XVII (13) \\
\hline Anal fin (modal formula) ${ }^{1}$ & III $(10-11)$ & III $(9-11)$ & III $(8-10)$ \\
\hline Features of pharyngeal bone ${ }^{2}$ & $\begin{array}{l}\text { Area toothed with } \\
\text { irregular density. }\end{array}$ & $\begin{array}{l}\text { Upper lobes well marked. } \\
\text { Dentate area with } \\
\text { low density. }\end{array}$ & $\begin{array}{l}\text { Upper lobes and superior } \\
\text { bone nearly straight or } \\
\text { very poorly developed. }\end{array}$ \\
\hline Features of pharyngeal teeth bone ${ }^{2}$ & $\begin{array}{l}\text { Bicuspid teeth in the upper } \\
\text { and monocuspids curved } \\
\text { backwards at the bottom. }\end{array}$ & $\begin{array}{l}\text { Fine and thin } \\
\text { monocuspids teeth. }\end{array}$ & $\begin{array}{l}\text { Presence mostly } \\
\text { monocuspids teeth with } \\
\text { very little presence of } \\
\text { bicuspid teeth. }\end{array}$ \\
\hline $\begin{array}{l}\text { Presence of regular vertical and well } \\
\text { defined stripes in the caudal fin }{ }^{1}\end{array}$ & Present & No present & Present \\
\hline
\end{tabular}

${ }^{1}$ Trewavas (1983).

${ }^{2}$ Arredondo-Figueroa \&Tejeda-Salinas (1989).

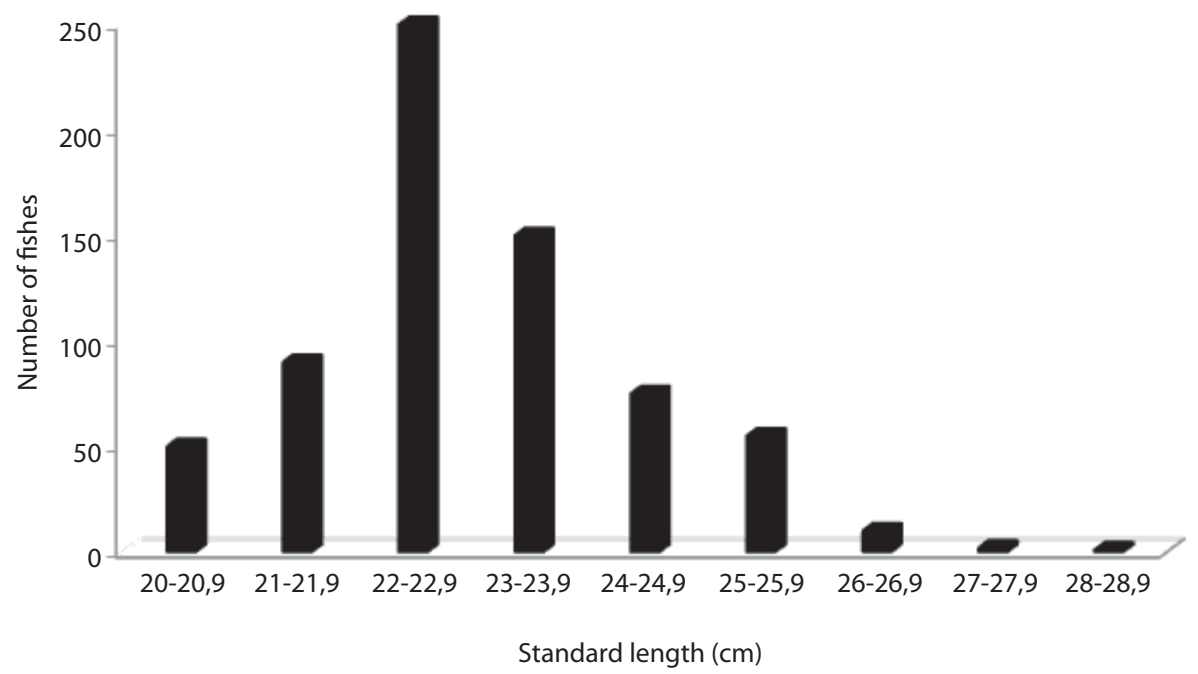

Fig. 1. Quantity of tilapia Oreochromis aureus x Orechromis niloticus by standard length (cm). 


\section{SIZE AT FIRST MATURITY}

Based on the logistic model proposed by Sparre \& Venema (1997), the reproductive maturity length was obtained. In the case of females (Fig., 3), the estimated length was $20,8 \mathrm{~cm}$. In the case of males it was $22,2 \mathrm{~m}$ (Fig. 4).

The fecundity ranged from 255 to 6930 eggs per female, with an estimated mean fecundity of $3133 \pm 1826$ $( \pm$ S.D.). Mature gonads corresponded to organisms between 20,0 and $25,9 \mathrm{~cm} \mathrm{~S}_{\mathrm{L}}$ and 200 to $750 \mathrm{~g} T_{\mathrm{w}}$. The minimum size recorded with mature gonads was $20,0 \mathrm{~cm} S_{L}$ and $200 \mathrm{~g}$ of $T_{w}$ and maximum of $25,9 \mathrm{~cm} \mathrm{~S}$ and $400 \mathrm{~g} T_{w}$. A significant relationship was found between $S_{L}$ and fecundity $(\mathrm{R}=0,870 ; P<0,05)$. There was a relationship between fecundity and $T_{\mathrm{W}}(\mathrm{R}=0,806 ; P<0,05)$ as well. Higher fecundity value was observed in females between 21 and $25 \mathrm{~cm} \mathrm{~S} S_{L^{\prime}}$ and between 400 and $800 \mathrm{~g}$ total weight (Figs. 5-6).

Gonadosomatic Index: The monthly gonadosomatic index showed two peaks, one during May and the second in November in both sexes (Fig. 7).

Percentage of each gonadal development stage is illustrated in figures 8 and 9 . According to females gonadic

TABLE 2

Sexual distribution of (Oreochromis aureus $x$ Oreochromis niloticus) by month.

\begin{tabular}{lccccc}
\multicolumn{1}{r}{ Month } & Females & Males & Total & $X^{2}$ & $p$-value \\
January & 16 & 25 & 41 & 3,240 & $\mathrm{~ns}$ \\
February & 15 & 20 & 35 & 1,250 & $\mathrm{~ns}$ \\
March & 12 & 25 & 37 & 6,760 & $*$ \\
April & 27 & 20 & 47 & 2,450 & $\mathrm{~ns}$ \\
May & 29 & 27 & 56 & 0,148 & $\mathrm{~ns}$ \\
June & 30 & 29 & 59 & 0,034 & $\mathrm{~ns}$ \\
July & 25 & 20 & 45 & 1,250 & $\mathrm{~ns}$ \\
August & 23 & 18 & 41 & 1,389 & $\mathrm{~ns}$ \\
September & 28 & 20 & 48 & 3,200 & $\mathrm{~ns}$ \\
October & 25 & 17 & 29 & 3,765 & $\mathrm{~ns}$ \\
November & 17 & 12 & 25 & 2,083 & $\mathrm{~ns}$ \\
December & 15 & 10 & 24305 & 0.803 & \\
Total & 262 & 243 & &
\end{tabular}

*Values significant at $p<0,05 ; \mathrm{ns}=$ no significant.

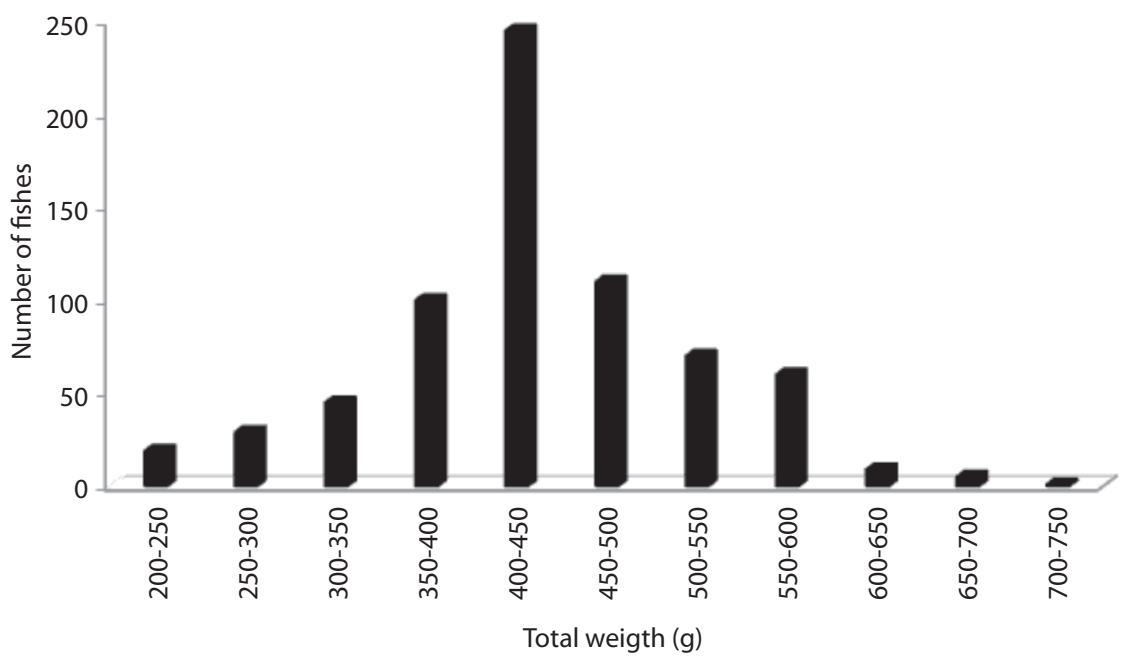

Fig. 2. Quantity of tilapia Oreochromis aureus x Orechromis niloticus by weight (g). 


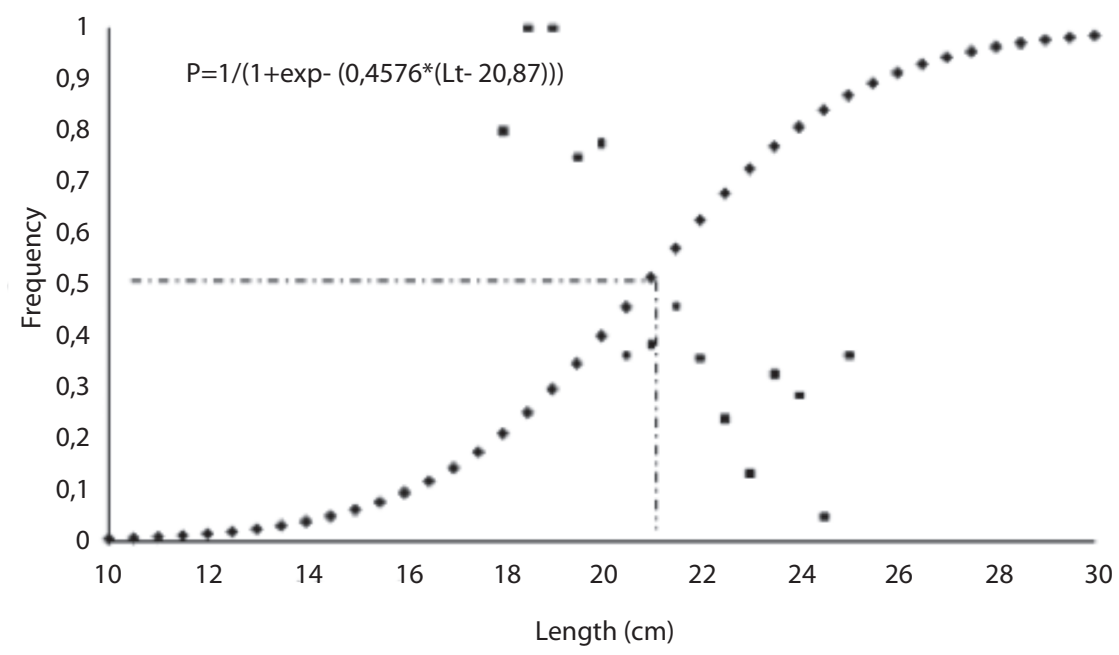

Fig. 3. Sexual maturity in Tilapia females (Oreochromis aureus x Oreochromis niloticus) from Zimapan reservoir.

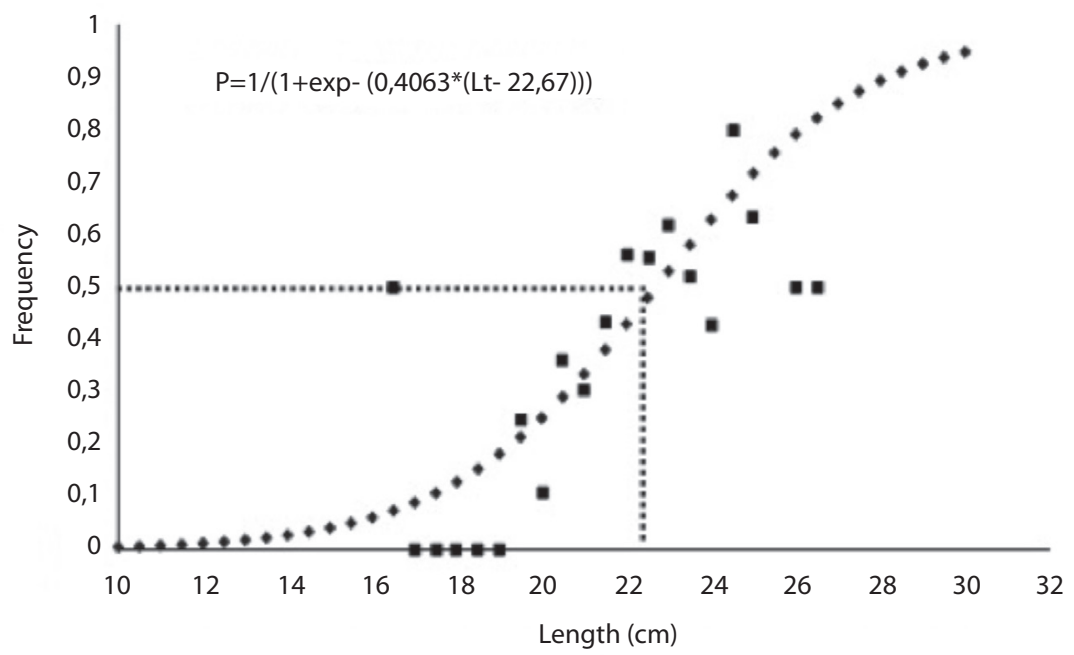

Fig. 4. Sexual maturity in Tilapia males (Oreochromis aureus x Oreochromis niloticus) from Zimapan reservoir.

maturation stages, $26,56 \%$ of the total fishes were maturing (II), 38,13\% were mature (III) and 10,94\% were ripe (IV) (Fig. 8). Therefore, $64,69 \%$ of the fish were in the reproductive process. In the males, $31,68 \%$ of the total fishes were maturing (II), 35,8\% were mature (III), and 19,75 $\%$ were ripe (IV) (Fig. 9). Therefore, $67,48 \%$ of the fishes were in the reproductive process. The highest proportion of average gonadal ripe stage (IV) in females was found in June and January (Fig. 2). However, from April-May and November there was a reproductive season.

The condition factor in both males and females was greater than 1 indicating that both are robust, and both showed similar variation patterns by month (Fig. 10). Males had the highest condition factor $(2,5)$. In both cases the highest values occurred in May and November (Fig. 10).

\section{DISCUSSION}

Reports on the hybridization capacity of Tilapia in the literature have been divided into three categories: 1) field observations on disturbed populations; 2) genetic studies of reproductive behavior; and 3) as tools to increase 


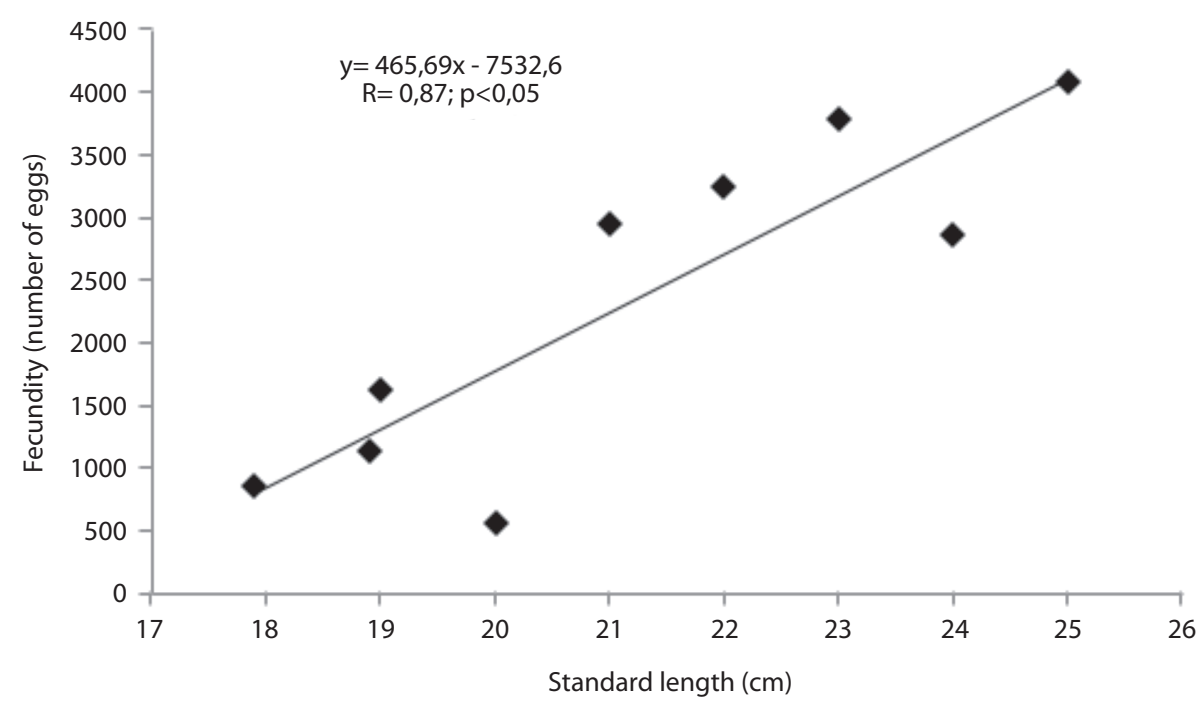

Fig. 5. Fecundity (number of eggs) and its relationship with length of the tilapia (Oreochromis aureus $x$ Oreochromis niloticus).

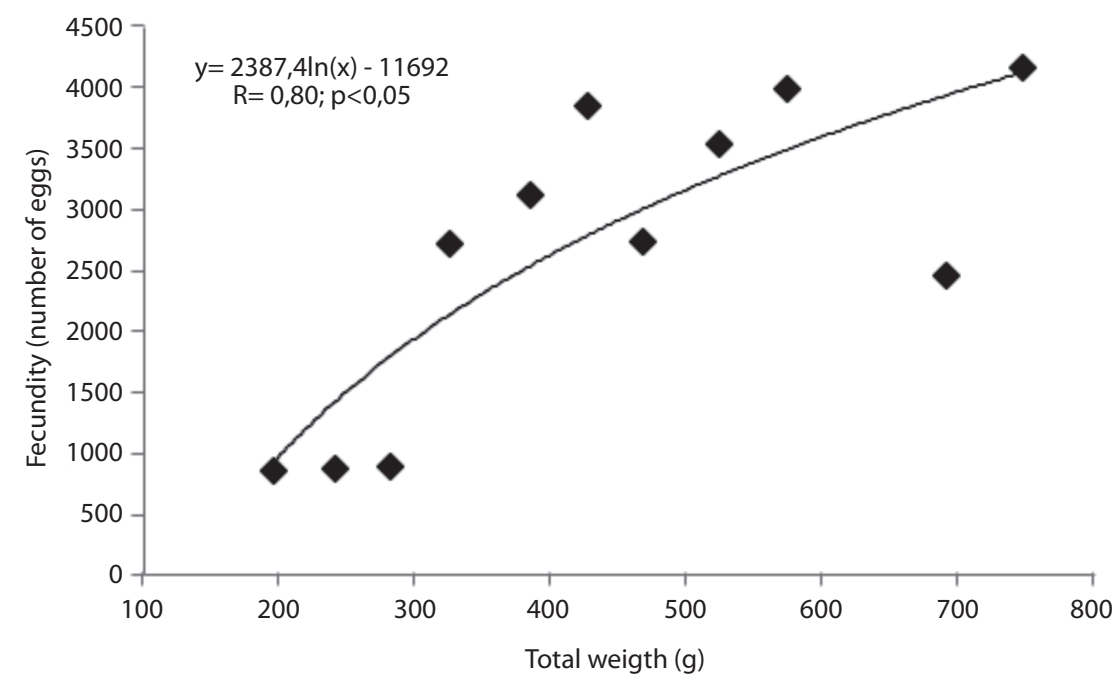

Fig. 6. Relationship between fecundity (number of eggs) and total weight of the tilapia hybrid (Oreochromis aureus $x$ Oreochromis niloticus).

aquaculture production. Hybridization has been documented by several different authors (Trewavas, 1983; Wohlfart, Moav \& Hulata, 1983; Pérez, Muñoz, Huaquin \& Nirchio, 2004; Bakhoum, Sayed-Ahmed \& Ragheb, 2009) and appears to be due to high crosslinking ability that Tilapia show as part of their reproductive strategy. This ability was observed in the present study as it was found that the Tilapia of the Zimapan reservoir share characteristics from two species of Tilapia originally introduced in to the reservoir (O. niloticus and O. aureus). This cross gave rise to a hybrid $O$. niloticus $X O$. aureus with special features as shown in Table 1. The hybridization capacity of Tilapia has been utilized in aquaculture in order to obtain fast growing and disease-resistant organisms, however inbreeding in natural conditions has been known to cause downsizing and internal organ malformation, so it might be necessary to take action to renew the gene pool, such as implementing periodic restocking of the reservoir (López-Hernández et al., 2007), in order to keep a sustainable fishery and conservation of this resource. 


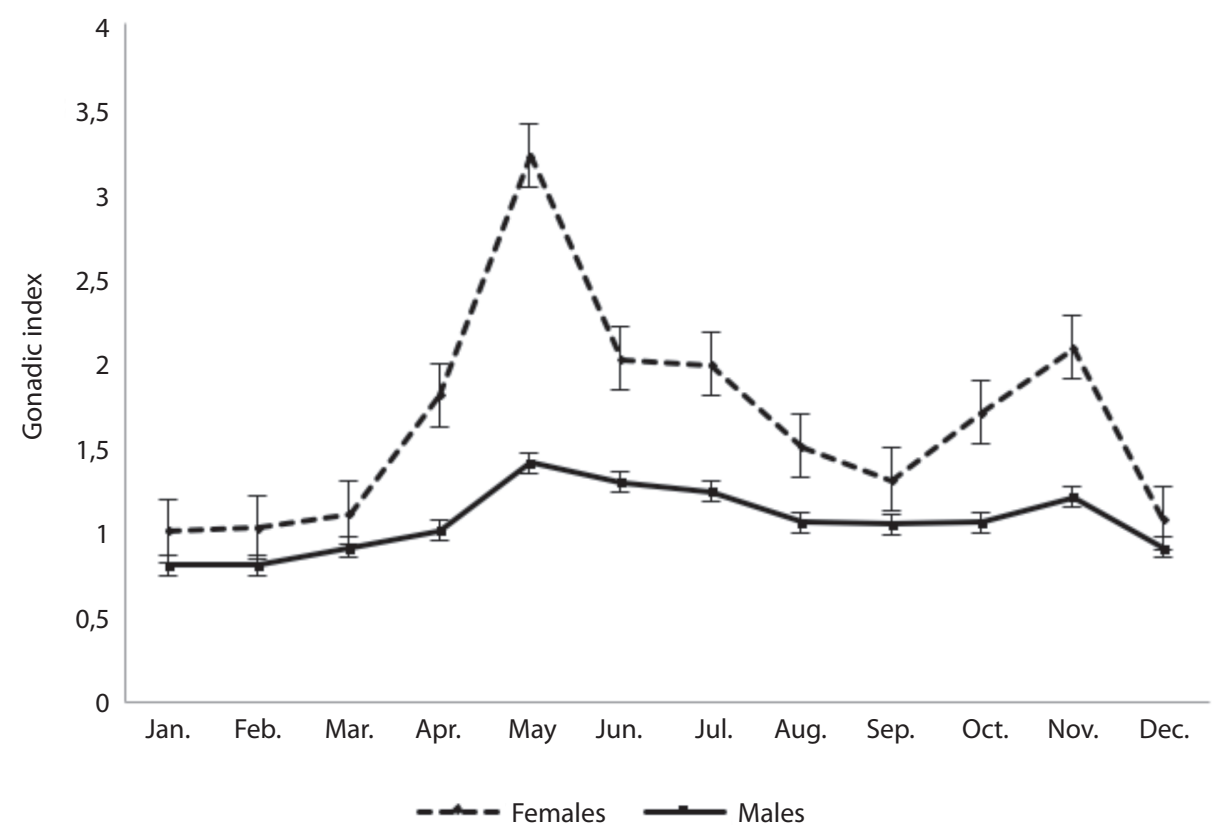

Fig. 7. Gonadosomatic index in Tilapia females (Oreochromis aureus x Oreochromis niloticus) by month.

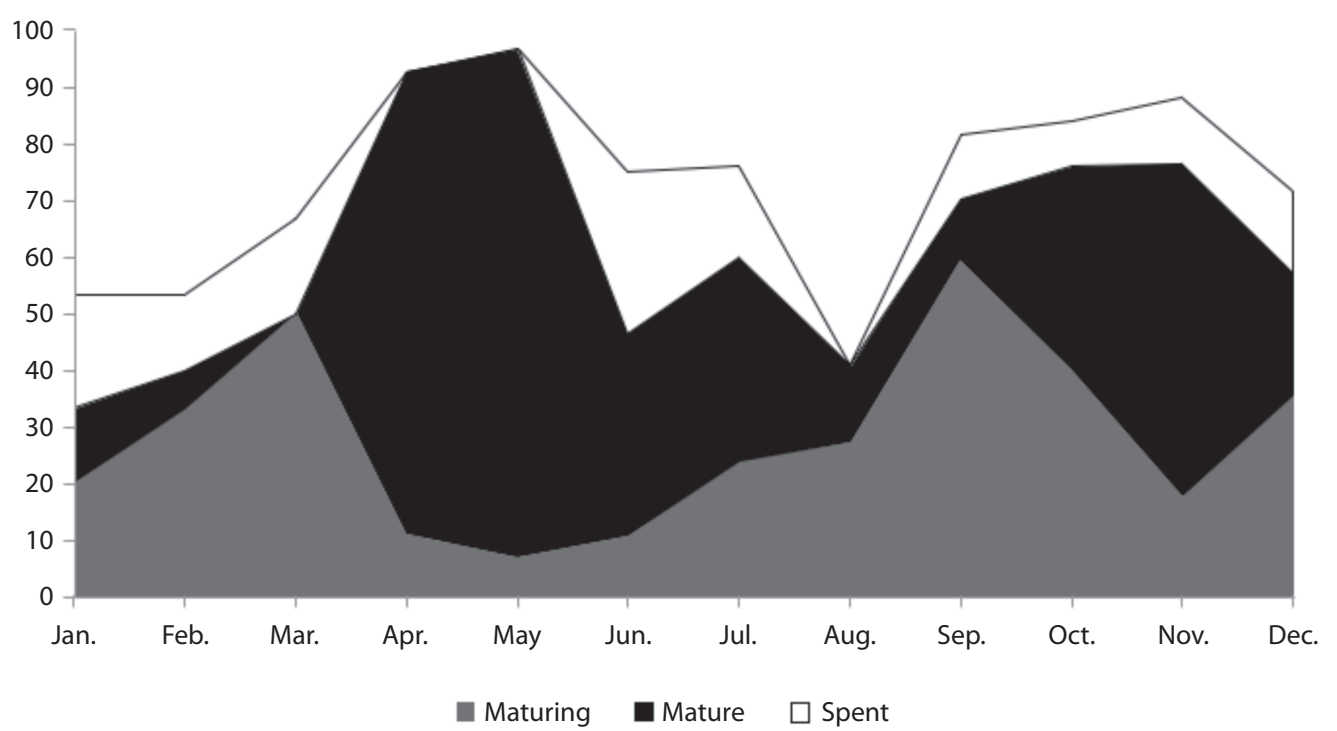

Fig. 8. Seasonal variation of maturity stages for Oreochromis aureus x Oreochromis niloticus ovaries.

Castillo (1989) and Arredondo, Beltrán \& Torres (1994) considered that sexual maturity in Tilapias is reached between $10-18 \mathrm{~cm}$ and a weight of $70-100 \mathrm{~g}$. Similarly, other authors like Cosson (2000), Huet (1978), and more recently Bocek (2003), found mature organisms of 0 . niloticus with a body height of 10 to $15 \mathrm{~cm}$. and weighing 40 to $100 \mathrm{~g}$, including other species like O. aureus who showed a minimum size of reproduction at $16 \mathrm{~cm}$ (Morales 1991). In the present work in Zimapan Dam, a length at reproductive maturity in females was observed at $20.8 \mathrm{~cm}$ and $22 \mathrm{~cm}$ in males. These results are in good agreement with Basurto (1995), who reported in the Chila Lagoon, Veracruz, Mexico, a minimum size at maturity of $23,5 \mathrm{~cm}$ in females and $24,0 \mathrm{~cm}$ in males of the 


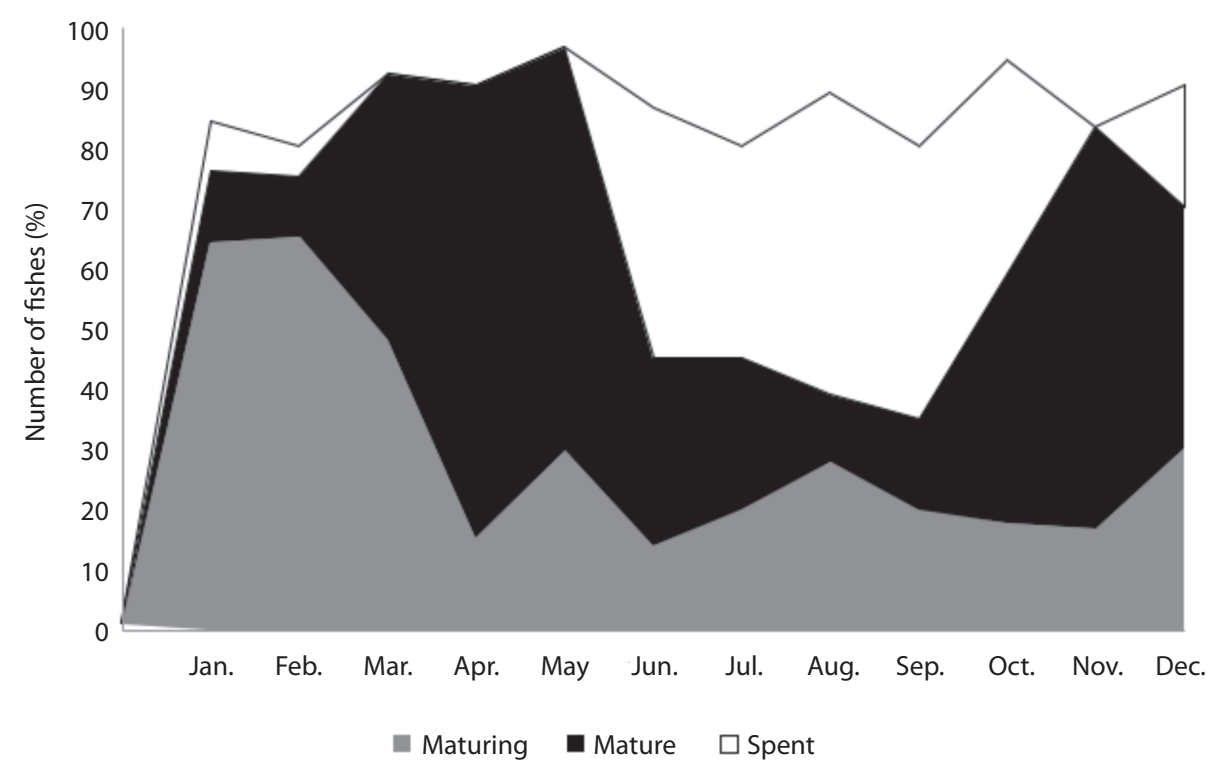

Fig. 9. Seasonal variation of maturity stages for Oreochromis aureus $x$ Oreochromis niloticus testis.

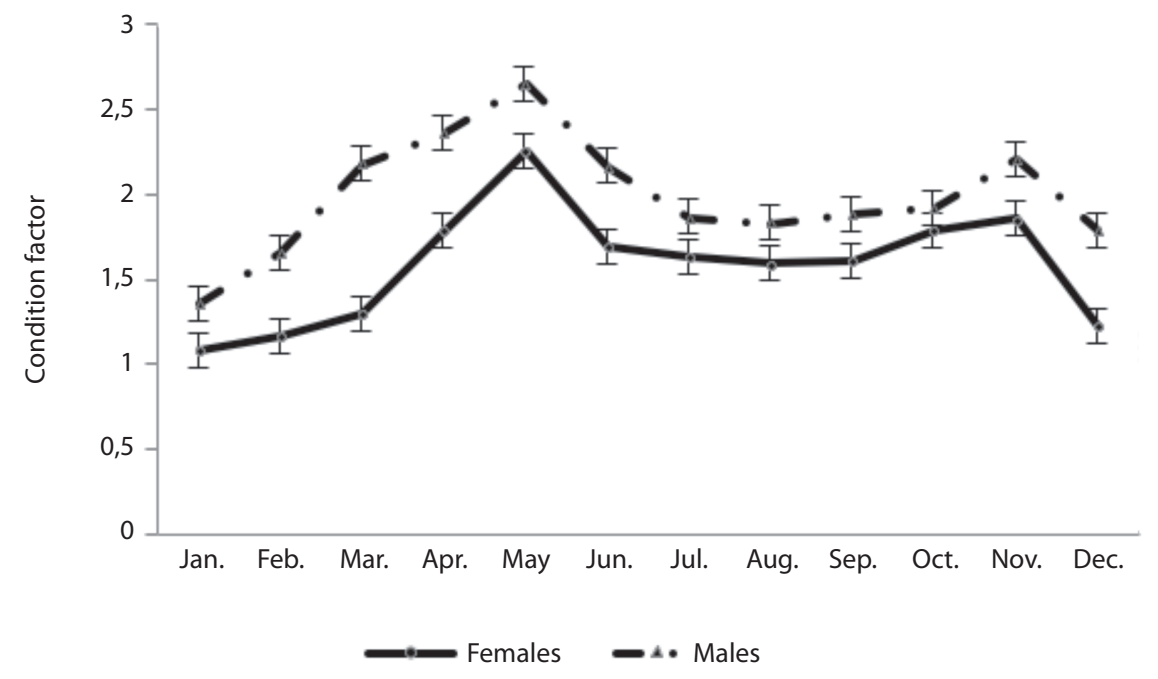

Fig. 10. Seasonal variation of condition factor $(\mathrm{k})$ in females and males of Oreochromis aureus $x$ Oreochromis niloticus.

Oreochromis niloticus, although the author mentioned that the commercial catch, due to the selectivity of fishing gear, did not represent fish under $20 \mathrm{~cm}$ long. More recently in South Arabia, Khallaf, Galal \& Authman (2003) reported that there is much variation in this parameter for Orechromis niloticus, influenced by human impacts and contamination of the sites where these fish live, together with the effect of the selectivity of fishing gear. Our results might be biased due to the selectivity of fishing gear concentrated in capturing the 21 to $25 \mathrm{~cm} \mathrm{~S}$ range of fish. It would be desirable to make collections of smaller sizes to verify these results. According to our results, it appear that the minimum catch size for local commercial fishery established for Tilapia in Zimapan Dam $\left(23,0 \mathrm{~cm} S_{L^{\prime}}\right.$ Hernández-Montaño \& Meléndez-Galicia, 2010), allows good conservation of the species, letting it to reach its reproductive size. By this procedure, mature organisms can reproduce and younger specimens are preserved. 
The sex ratio for $O$. niloticus $X O$. aureus in Zimapan reservoir indicate that the male and females are approximately equal in numbers and the deviation from the 1:1 ratio (male: female) was not significant. Nikolsky (1963) cited that the sex ratio varies considerably from species to species, but in the majority of cases it is close to one, and may vary from year to year in the same population. Other studies have also reported on the 1:1 sex ratio in Tilapia (Ramos-Cruz, 1995; Shallof \& Salama, 2008; Afamdi \& Peter, 2008), as in this study. It is important to highlight the fact that some catches (between January and March) have shown a mean male number greater than females, although no significance difference were observed, except in March (Table 1).

Morales (1974) estimated fecundity from 1000 to 1 800 eggs for female sizes between 31 and $33 \mathrm{~cm}$ long in the Miguel Aleman reservoir, in Oaxaca, Mexico. Fryer \& lles (1972) obtained a fecundity of 3706 eggs from a gigantic with total length of $57 \mathrm{~cm}$ of T. nilotica. JiménezBadillo (1999) reported for O. aureus at Adolfo Lopez Mateos Dam in Michoacán, a range of 625 to 1983 eggs for females from 13,9 to $28,0 \mathrm{~cm}$, with an average of 1 304 eggs. Moreover Peña-Mendoza, Gómez-Márquez, Salgado-Ugarte \& Ramirez-Noguera (2005) showed that Tilapias collected at Emiliano Zapata reservoir, Morelos, Mexico, presented a production of eggs from 243 to 847 in organisms from 15 to $25 \mathrm{~cm}$ long. The number of eggs produced in Zimapan reservoir gave an average of 3000 eggs for a range of 17,9 to $25,9 \mathrm{~cm} \mathrm{~S}_{L^{\prime}}$ in good agreement with our results. Apparently, the "Zimapan" Tilapia, once they have reached reproductive maturity, have a size range in which the follicles or egg production is optimal (Fig. 3), but in young Tilapia and older fishes, the number of eggs produced is lower. This fertility, coupled with the parental care shown by these organisms (Chapman, 2000), increase the chances of survival.

The gonad index showed two peaks, one in May and another in November. This is indicative of the reproductive capacity of this species, which has been reported as a species that can perform several partial spawning over a period of annual. These reproductive characteristics have been reported in different reservoirs in Mexico and other sites of the world. Gómez-Márquez, Peña-Mendoza, Salgado-Ugarte \& Guzman-Arroyo (2003), reported on Lake Morelos Coatetelco, two spawning periods for Oreochromis sp (June and December), Jiménez-Badillo (2006) found for blue Tilapia sp partial spawning, and has reported spawning peaks from May to August and October to November in Infiernillo reservoir. Shallof \& Salama (2008) reported that females of O. niloticus had several spawning peaks, observed in March, April, June and September in the Egyptian lake Abu-zabal. Morales
(1991) mentions that the frequency of spawning in Tilapia can vary considerably depending on environmental factors and Tilapia in Mexico might spawn up to 10 times per year. The same was reported by Afamdi \& Peter (2008) for a lake of Nigeria. For Zimapán reservoir, the gonadic index indicated the existence of two reproductive periods occurring in May and November, in good agreement with a previous observation reported by Hernández-Montaño \& Orbe-Mendoza (2002) and suggesting particular environmental conditions that only allow two reproductive seasons, compared to other reservoirs. This study revealed that fish closed season established from April to June (Hernández-Montaño \& OrbeMendoza, 1999; Hernández-Montaño y Orbe-Mendoza, 2002; Hernández-Montaño \&Melendez-Galicia, 2010; Arellano-Torres et al., 2013; SAGARPA, 2013), may have better results in preserve the local fisheries, considering that Tilapia has a second spawning peak in November as was observed in this study (Fig. 7). However, a more extent monitoring program needs to be performed by National authorities in order to justify this possibility, considering the amount of organisms from the whole population that is sexually mature, abundance and distribution in the reservoir and caught parameters on a year and monthly bases. This information will give the best season of capture according to national regulations for fish closed seasons (DOF, 2004). By establishing two closed seasons in Zimapan management program as our results suggest (April and November for example), better conservation of this resource could be reach, especially if we consider that the main productive activity in the region is the commercial fishery with a value greater than 2,3 million dollars or 30 million pesos per year (Hernández-Montaño \& Meléndez-Galicia, 2010). Now days, April's closed season allows a recovered in tilapia population and provides a greater volume of capture few months later (Hernández-Montaño \& Meléndez-Galicia, 2010). The same pattern could be developed if a second closed season is established exactly when caught volumes are reduced, as has been observed in March and November for tilapia in Zimapan (Hernández-Montaño \& Meléndez-Galicia, 2010). It is important to highlight that from a genomic point of view, Mexican regulation (DOF, 2000) does not considered hybrids of tilapia, only pure lineage, leaving it without suitable regulation. Therefore, we can conclude that these fishes are still eligible for commercial exploitation and its conservation, under the actual fishery management regulations can be improve by extending the fish closed season to a second period in November, by local authorities and fishermen, that could induce a higher volumes of captures (and income) few months later, just before the fish closed season of April. 


\section{ACKNOWLEDGMENT}

We thank Hernán Álvarez Guillén and Andres Reda Deara for their comments and suggestions regarding the investigation. Special thanks to the authorities of SAGARPA, Hidalgo and Queretaro States, specifically their Department of Fisheries, for their support in carrying out the study, Enrique Núñez-Jiménez. and Stuart Furton for improving this manuscript.

\section{REFERENCES}

Afamdi, A., \& Peter, U. O. (2008). Some aspects of the reproductive biology of Tilapia mariae (Boulenger 1901) in a small lake in southeasten Nigeria. African Journal of Biotechnology, 7(14), 2478-2482.

Arredondo, B., Beltrán, A., \& Torres, M. (1994). Desarrollo científico y tecnológico del banco de genoma de tilapia. México: SEPESCA.

Arredondo-Figueroa, J. L., \& Guzmán-Arroyo, M. (1986). Actual situación taxonómica de las especies de la Tribu Tilapiini (Pisces: Cichlidae) introducidas en México. Anales del Instituto de Biología-UNAM. Serie zoología, 56(2), 555-572.

Arredondo-Figueroa, J. L., \& Tejeda-Salinas, M. (1989). El hueso faríngeo, una estructura útil para la identificación de especies de la tribu Tilapiini (Pisces: Cichlidae), introducidas en México. Anales del Instituto de Ciencias del Mary Limnología-UNAM, 16(1), 59-68.

Arrellano-Torres, A., Hernández-Montaño, D., \& MeléndezGalicia, C. (2013). Comparación de tres métodos indirectos para estimar el crecimiento de tilapia Oreochromis aureus (Perciformes: Cichlidae) en un lago tropical de México. Revista de Biología Tropical, 61(3), 1301-1312. 77442013000400024

Bakhoum, S. A., Sayed-Ahmed, M. A., \& Ragheb, E. A. (2009). Genetic evidence for natural hybridization between Nile Tilapia (Oreochromis niloticus; Linnaeus, 1757) and Blue Tilapia (Oreochromis aureus; Steindachner, 1864) in Lake Edku, Egypt. Global Veterinaria, 3(2), 91-97.

Basurto, M. (1995). Algunos aspectos reproductivos de la tilapia Oreochromis niloticus en la Laguna de Chila, Veracruz. Centro Regional de Investigación Pesquera en Puerto Morelos. México. Biotam, 6(3), 32-41.

Bermúdez, E. A. (2007). Evaluación pesquera de la presa Fernando Hiriart Balderrama "Zimapán" Hidalgo-Querétaro México, 2003-2005 y elementos técnicos para el establecimiento de la veda para todas las especies. Opinión Técnica INP anexo. México: Comisión Federal de Mejora Regulatoria. Recuperado de http://www.cofemermir.gob.mx/mir/up loadtests/6979.66.59.2.Evaluacion\%20Zimapan.pdf

Bocek, A. (2003). Reproductive biology of Oreochromis niloticus. Alabama, USA: International Center for Aquaculture and Aquatic Enviroment.
Castillo, F. L. (1989). Historia genética e hibridación de la tilapia roja. Colombia: SEDEPESCA.

Cosson, J. (2000). Acuicultura en acuatorios naturales, Aquatic 10. National Center for Scientific Research. Villefranse sur Mer.

Chapman, F. A. (2000). Culture of Hybrid Tilapia: A Reference Profile. University of Florida, Gainesville: Institute of Food and Agricultural Sciences. Recuperado de http:// edis.ifas.ufl.edu/pdffiles/FA/FA01200.pdf.

de Vlaming, V., Grossman, G., \& Chapman, F. (1982). On the use of gonadosomatic index. Comparative Biochemistry and Physiology-Part A, 73(1), 31-39.

Diario Oficial de la Federación (DOF). (1994). Norma Oficial Mexicana NOM-009-PESC-1993, que establece el procedimiento para determinar las épocas y zonas de veda para la captura de las diferentes especies de la flora y fauna acuáticas, en aguas de jurisdicción federal de los Estados Unidos Mexicanos. 4 de marzo de 1994. México. D.F. Recuperado de http://www.conapesca.sagarpa.gob. $\mathrm{mx} /$ work/sites/cona/resources/LocalContent/8739/15/ 009pesc1994VEDAS.pdf

Diario Oficial de la Federación (DOF). (2000). Norma Oficial Mexicana NOM-028-PESC-2000, Pesca responsable en la presa Ing. Fernando Hiriart Balderrama (Zimapán), Hidalgo y Querétaro. Especificaciones para el aprovechamiento de los recursos pesqueros. 31 de octubre de 2000. México. D.F. Recuperado de http://www.conapesca.sagarpa.gob.mx/work/sites/cona/resources/LocalContent /8739/15/028pesc2000ZIMAPAN.pdf

Diario Oficial de la Federación (DOF). (2007). Modificación a la Norma Oficial Mexicana NOM-028-PESC-2000, Pesca responsable en la presa Ing. Fernando Hiriart Balderrama (Zimapán), Hidalgo y Querétaro. Especificaciones para el aprovechamiento de los recursos pesqueros. 3 de abril de 2007. México. D.F. Recuperado de http://diariooficial.segob.gob.mx/nota_to_doc.php?codnota $=4967167$

Fryer, G., \& lles, T. D. (1972). The Cichlid Fishes of the Great Lakes of Africa. Their Biology and Evolution. Edinburgh, Scotland: Oliver and Boyd.

Gómez-Márquez, J. L., Peña-Mendoza, B., Salgado-Ugarte, I. H., \& Guzman-Arroyo, M. (2003). Reproductive aspects of Oreochromis niloticus (Perciformes: Cichlidae) at Coatetelco lake Morelos, Mexico. Revista de Biología Tropical, 51(1), 221-228.

Gómez-Ponce, M. A., Granados-Flores, K., Padilla, C., LópezHernández, M., \& Núñez-Nogueira, G. (2011). Edad y crecimiento del híbrido de tilpia Oreochromis niloticus $x$ Oreochromis aureus (Perciformes: Cichlidae) en la represa "Zimapán" Hidalgo, México. Revista de Biología Tropical, 59(2), 761-770.

Hernández-Montaño, D., \& Meléndez-Galicia, C. (2010). Dictamen Técnico. Ratificación del periodo de veda (2010) en la Presa Fernando Hiriart Valderrama (Zimapán) Hgo.-Qro. Centro Regional de Investigación Pesquera Pátzcuaro, Instituto Nacional de la Pesca, México: SAGARPA. Recuperado de http://www.cofemermir. 
gob.mx/mir/uploadtests/19610.66.59.13.Dictamen\%20 veda\%20zimapan.pdf

Hernández, D., \& Orbe M., A. (1999). Evaluación Pesquera de la presa Fernando Hiriart

Balderrama (Zimapán) Hidalgo-Querétaro, México. Informe Técnico, Centro Regional de

Investigación Pesquera de Pátzcuaro. México: Instituto Nacional de la Pesca.

Hernández-Montaño, D., \& Orbe-Mendoza, A. A. (2002). Evaluación pesquera de la presa Fernando Hiriart Balderrama (Zimapán) Hidalgo-Querétaro, México (pp.437-457). En De la Lanza-Espino, G. \& GarcíaCalderón, J. L. (Eds.). Lagos y presas de México. México: Secretaria de Pesca.

Huet, M. (1978). Tratado de Piscicultura. Madrid, España: Mundi-Prensa.

Jiménez-Badillo, M. L. (1999). Análisis de la Pesquería de Tilapia Oreochromis spp (Pisces: Cichlidae) en la Presa Adolfo López Mateos, Michoacán-Guerrero. (Tesis inédita de Doctorado). Instituto de Ciencias del Mar y Limnología, Universidad Nacional Autónoma de México, México.

Jímenez-Badillo, M. L. (2006). Age-growth models for tilapia Oreochromis aureus (Perciformes, Cichlidae) of the Infiernillo reservoir, Mexico and reproductive behaviour. Revista de Biología Tropical, 54(2), 277-588.

Khallaf., E. A., Galal, M., \& Authman, M. (2003). The biology of Oreochromis niloticus in a polluted canal. Ecotoxicology, 12(5), 405-416. doi: 10.1023/A:1026156222685

López-Hernández, M., Ramos, G., Gómez-Ponce, M. A., FigueroaTorres, M., \& Carranza-Fraser, J. (2007). Aspectos limnológicos, de impacto ambiental y pesqueros en la presa hidroeléctrica Zimapán, Hidalgo-Querétaro ( $\mathrm{pp}$. 801-820). En Arredondo, J., Díaz, G., \& Ponce, J. (Eds.). Limnología de presas mexicanas. México: AGT Editor, S.A.

Morales, A. (1974). El cultivo de la tilapia en México. Datos biológicos. México: Instituto Nacional de la Pesca.

Morales, D. A. (1991). La tilapia en México, biología, cultivo y pesquerías. México: AGT Editor.

Nikolsky, D. V. (1963). The ecology of fishes. Part II. New York: Academic Press.
Peña-Mendoza, B., Gómez-Márquez, J. L., Salgado-Ugarte, I. H., \& Ramírez-Noguera, D. (2005). Reproductive biology of Oreochromis niloticus (Perciforme: Cichlidae) at Emiliano Zapata dam, Morelos, México. Revista de Biología Tropical, 53(3-4), 515-522.

Pérez, E., Muñoz, J. C., Huaquín, L., \& Nirchio, M. (2004). Riesgos de la introducción de tilapias (Oreochromis sp.) (Perciformes:Cichlidae) en ecosistemas acuáticos de Chile. Revista Chilena de Historia Natural, 77(1), 195-199.

Ramos-Cruz, S. (1995). Reproducción y crecimiento de la mojarra tilapia (Oreochromis aureus) en la Presa Benito Juárez, Oaxaca, México, en 1993. Ciencia Pesquera, 11, 54-61.

Secretaria de Agricultura, Ganadería Desarrollo Rural, Pesca y Alimentación (SAGARPA). (2008). Anuario estadístico de Acuacultura y Pesca. México: SEPESCA. Recuperado de http://www.conapesca.sagarpa.gob.mx/wb/cona/ anuario2008

Secretaria de Agricultura, Ganadería Desarrollo Rural, Pesca y Alimentación (SAGARPA). (2013). Boletín 033/2013. ModificaSAGARPA periodo de vedaparala pescaen la presa Zimapán. México. Secretaria de Agricultura, Ganadería, Desarrollo rural, Pesca y Alimentación. Recuperado de http://www.sagarpa.gob.mx/Delegaciones/queretaro/ boletines/2013/marzo/Documents/2013B033.pdf

Shalloof, K. A. Sh., \& Salama, H. M. M. (2008). Investigations on some aspects of reproductive biology in Oreochromis niloticus (Linnaeus, 1757) Inhabited Abu-zabal lake Egypt. Global Veterinaria, 2(6), 351-359.

Sparre, P., \& Venema, S. C. (1997). Introduction to tropical fish stock assessment. Part 1 Manual. (FAO Fisheries Technical Paper. No. 306.1, Rev. 2). Rome: Food and Agriculture Organization (FAO). Recuperado de http://www.fao.org/ docrep/008/w5449s/w5449s00.htm

Trewavas, E. (1983). Tilapiine fishes of the genera Sarotherodon, Oreochromis and Danakilia. London: Museum of Natural History.

Wohlfart, G. W., Moav, R., \& Hulata, G. (1983). A genotypeenvironment interaction for growth rate in the common carp, growing in intensively manured ponds. Aquaculture, 33(1-4), 187-195. doi: http://dx.doi. org/10.1016/0044-8486(83)90399-X 
